\title{
Pengembangan Multimedia Pembelajaran Interaktif Berbasis Masalah Kontekstual Pada Materi Himpunan untuk Memfasilitasi Kemampuan Pemecahan Masalah Matematis Siswa Sekolah Menengah Pertama
}

\author{
Sunarsih Puji Lestari ${ }^{1}$, Hayatun Nufus ${ }^{2}$, Ramon Muhandaz ${ }^{3}$ \\ ${ }^{1,2,3}$ Program Studi Pendidikan Matematika, Fakultas Tarbiyah dan Keguruan, Universitas Islam Negeri Sultan Syarif Kasim \\ JL. H.R. Soebrantas Km.15 Simpang Baru- Tampan Pekanbaru \\ sunarsih.pujilestari@gmail.com
}

\begin{abstract}
This research is motivated by the results of the survey showing that the development of interactive multimedia as a means of increasing student competence so that students are able to solve mathematical problems is still rare in schools. This research aimed at developing valid, practical, and effective interactive learning multimedia to facilitate student mathematical problem-solving ability. It was a Research and Development with ADDIE model. It was administered at Juara Junior High School Pekanbaru at the first semester in the Academic Year of 2019-2020. The data collected were qualitative and quantitative. Questionnaire and test were the techniques of collecting the data, and the instruments were in the forms of validation questionnaire, practicality questionnaire, and mathematical problem-solving ability test items. The data were processed and analyzed by using descriptive (for validation and practicality tests) and inferential (for effectiveness test) statistical data analysis techniques. The research findings showed that the learning multimedia developed was on the categories of Very Valid (83.67\%), Very Practical (83.61\% for small group and 87.02\% for limited group), and Effective (the mean of experimental group was 69.33 and the control group was 35.61 ), The conclusion from this research is to produce interactive multimedia based on contextual problems that are valid, practically used by students and are effective in improving specific mathematical problem-solving abilities on himpunan material.
\end{abstract}

Keywords: Development, Multimedia Learning, Contextual Problems, Mathematical Problem Solving Abilities

\begin{abstract}
Abstrak
Penelitian ini dilatar belakangi dari hasil survei menunjukkan bahwa pengembangan multmedia interaktif sebagai sarana untuk meningkatkan kompetensi siswa sehingga siswa mampu menyelesaikan masalah matematis masih jarang ada di sekolah. Penelitian juga bertujuan untuk menghasilkan multimedia pembelajaran interaktif yang valid, praktis, dan efektif dalam memfasilitasi kemampuan pemecahan masalah matematis siswa. Penelitian ini merupakan penelitian dan pengembangan dengan menggunakan model ADDIE. Penelitian ini dilakukan di SMP Juara Pekanbaru pada semester ganjil tahun ajaran 2019-2020. Jenis data yang diambil dalam penelitian ini adalah data kualitatif dan kuantitatif. Data dikumpulkan menggunakan teknik angket dan teknik tes dengan instrumen berupa angket validasi, angket praktikalitas dan soal tes kemampuan pemecahan masalah matematis. Data diolah dan dianalisis dengan menggunakan teknik analisis data statistik deskriptif (untuk uji validitas dan reliabilitas) dan statistik inferensial (untuk uji efektifitas). Hasil penelitian menunjukkan bahwa multimedia pembelajaran yang dikembangkan berada pada tingkat kategori sangat valid $(83,67 \%)$, sangat praktis $(83,61 \%$ untuk kelompok kecil dan 87,02\% untuk kelompok terbatas) dan efektif (dengan rata-rata kelas eksperimen 69,33 dan kelas kontrol 35,61). Kesimpulan yang didapat dari penelitian ini adalah menghasilkan multimedia interaktif berbasis masalah kontekstual yang valid, praktis digunakan siswa serta efektif dalam meningkatkan kemampuan pemecahan masalah matematis khusus pada materi himpunan.
\end{abstract}

Kata Kunci: Pengembangan, Multimedia Pembelajaran, Masalah Kontekstual, Kemampuan Pemecahan Masalah Matematis

Copyright (c) 2021 Sunarsih Puji Lestari, Hayatun Nufus, Ramon Muhandaz

$\triangle$ Corresponding author: Ramon Muhandaz

Email Address: ramon.muhan@uin-suska.ac.id (Jl. H.R Soebrantas Km.15 Simpang Baru, Pekanbaru)

Received 07 Desember 2020, Accepted 14 Februari 2021, Published 18 Februari 2021 


\section{PENDAHULUAN}

Media yang baik sangat dibutuhkan untuk keberhasilan belajar. Siswa membutuhkan media yang memudahkan mereka menerima materi dalam proses belajar. Berkaitan dengan hal itu, saat ini berkembang suatu tren dimana siswa lebih banyak menghabiskan waktu menggunakan dunia maya lewat teknologi, baik itu komputer, laptop, tablet atau smartphone dalam melakukan aktivitasnya seperti belajar, bersilaturahmi, maupun bermain. Berdasarkan laporan yang disampaikan oleh Balitbang tentang survey penggunaan TIK tahun 2017, menyarankan agar penggunaan komputer dalam durasi cukup lama hendaknya diarahkan untuk hal positif seperti pencarian informasi baru atau kegiatan produktif yang dapat meningkatkan pengetahuan dan perekonomian, bukan hanya untuk kebutuhan rekreasi seperti musik dan game. Salah satu media belajar yang menggunakan komputer sebagai akses untuk membantu siswa menerima materi atau pengetahuan adalah multimedia pembelajaran interaktif.

Faktanya dilapangan, berdasarkan data BPS(Badan Pusat Statistik, 2018) Survei Penggunaan dan Pemanfaatan Teknologi Informasi dan Komunikasi di sektor pendidikan ini dilakukan terhadap 4.014 sekolah yang tersebar di 34 provinsi. Berdasarkan jenjang pendidikan, SD dan sederajat sebanyak 64,55 persen, SMP dan sederajat sebanyak 19,22 persen dan SMA dan sederajat sebanyak 16,23 persen. Hal ini juga sejalan hasil wawancara yang dilakukan ke sekolah dengan kesimpulan penggunaan multimedia sebagai sarana pembelajaran jarang digunakan. Maka oleh sebab itu, peneliti ingin mengembangkan sebuah multimedia pembelajaran sebagai salah satu sarana dalam proses pembelajaran yang akan digunakan di kelas.

Multimedia pembelajaran itu sendiri dapat diartikan sebagai aplikasi multimedia yang digunakan dalam proses pembelajaran, dengan kata lain untuk menyalurkan pesan (pengetahuan, keterampilan dan sikap) serta dapat merangsang pilihan, perasaan, perhatian dan kemauan peserta didik, sehingga secara sengaja proses belajar tu terjadi, bertujuan dan terkendali(Munir, 2013). Sedangkan menurut Wina Sanjaya(Wina, 2012) pembelajaran melalui multimedia adalah pembelajaran yang didesain dengan menggunakan berbagai media secara bersamaan seperti teks, gambar (foto), film (video) dan lain sebagainya yang kesemuanya saling bersinergi untuk mencapai tujuan pembelajaran yang dirumuskan sebelumnya. Maka multimedia pembelajaran interaktif kurang lebih dapat diartikan sebagai aplikasi multimedia yang digunakan dalam proses pembelajaran dengan pola komunikasi dua arah sebagai aspek interaktif dan didesain sesuai dengan tujuan pembelajaran.

Adapun faktor yang mempengaruhi dalam memilih multimedia pembelajaran menurut Munir (Munir, 2013)diantaranya : (a) kemampuan yang akan dicapai sesuai dengan tujuan, (b) kegunaan multimedia pembelajaran, (c) kemampuan pendidik menggunakan multimedia pembelajaran, (d) fleksibilitas (lentur), tahan lama dan kenyamanan multimedia pembelajaran.

Beberapa referensi (Arifin, Ricky, \& Yesmaya, 2015; Munir, 2013) menunjukkan bahwa komponen multimedia pembelajaran interaktif meliputi: teks, suara, grafik, animasi, video dan interaktifitas. Sedangkan menurut Torn kriteria atau indikator yang digunakan untuk menilai 
Pengembangan Multimedia Pembelajaran Interaktif Berbasis Masalah Kontekstual Pada Materi Himpunan untuk Memfasilitasi Kemampuan Pemecahan Masalah Matematis Siswa Sekolah Menengah Pertama, Sunarsih Puji Lestari, Hayatun Nufus, Ramon Muhandaz

multimedia pembelajaran interaktif yaitu : (a) kemudahan navigasi, (b) kandungan kognisi, dalam artian adanya kandungan pengetahuan yang jelas, (c) presentasi informasi, (d) integrasi media, (e) artistik dan estetika, (f) fungsi secara keseluruhan. Selain itu menurut Pandingan dkk (dalam Asmi, Rahmat, \& Muhandaz, 2021) Untuk memenuhi tuntutan angkatan 21, media pembelajaran digunakan harus memiliki fitur 4C: Komunikasi, Kolaborasi, Berpikir Kritis dan pemecahan masalah, Kreatif dan Inovati.

Multimedia pembelajaran interaktif dapat dimanfaatkan oleh guru untuk mengemas materi pembelajaran di sekolah, terutama dalam pembelajaran matematika. Berkaitan dengan matematika, sering terdengar keluhan beberapa orang yang telah mempelajari matematika tapi tidak mampu mengkaitkan dengan keadaan di lingkungan yang nyata. Maka dibutuhkan contoh-contoh masalah matematika yang tidak hanya membahas soal-soal abstrak, namun lebih kepada konteks masalah dalam dunia nyata. Untuk mengatasi masalah tersebut maka salah satu caranya adalah dengan membahas masalah kontekstual dalam pembelajaran matematika.

Masalah kontekstual terdiri dari dua kata yaitu masalah (problem) dan konteks. Menurut Krulik dkk mendefenisikan problem "A problem is a situation, quantitative or otherwise, that confronts an individual or group of individuals, that requires resolution, and for which the individual sees no apparent path to obtaining the solutions(Krulik, Rudnick, \& Milou, 2003)" yang dapat diartikan bahwa suatu masalah adalah sebuah situasi, tentang kuantitas atau lainnya yang dihadapi oleh seorang individu atau kelompok yang memerlukan penyelesaian, yang mana individu memandang tidak ada cara untuk memperoleh penyelesaian, sedangkan konteks menurut Nelissen(Nelissen, 1999) "A context is a situation which appeals to children and which they can recognize in theory" mendefinisikan konteks sebagai situasi yang menarik perhatian anak dan yang mereka dapat kenali dengan baik. Jadi dapat disimpulkan masalah kontekstual tersebut adalah masalah matematika dapat berkaitan langsung dengan obyek nyata, atau berkaitan dengan obyek dalam pikiran yang membutuhkan penyelesaian.

Pembelajaran matematika yang diajarkan di sekolah tentunya memiliki kemampuankemampuan yang hendak dicapai, salah satunya adalah kemampuan pemecahan masalah. Kemampuan ini menjadi penting karena berdasarkan lampiran dalam Peraturan Menteri Pendidikan dan Kebudayaan (Permendikbud) No. 21 tahun 2016 tentang Standar Isi Pendidikan Dasar dan Menengah, kemampuan pemecahan masalah termasuk dalam kompetensi yang diharapkan untuk tingkat kompetensi kelas VII-IX. Ini menunjukkan pentingnya kemampuan pemecahan masalah terutama pada pembelajaran matematika.

Menurut Polya, pemecahan masalah adalah suatu usaha mencari jalan keluar dari suatu tujuan yang tidak begitu mudah segera dapat dicapai (Hendriana, Rohaeti, \& Sumarmo, 2017). Pemecahan masalah juga diartikan sebagai suatu aktivitas intelektual untuk mencari penyelesaian masalah yang dihadapi dengan menggunaan bekal pengetahuan yang sudah dimiliki (Nissa, 2015). Maka dapat 
disimpulkan bahwa kemampuan pemecahan masalah matematis merupakan kemampuan menyelesaikan masalah matematis yang belum diketahui secara langsung cara penyelesaiannya, dengan memanfaatkan pengetahuan sebelumnya tentang konsep yang berkaitan.

Menurut Siswono(Norhayati, Hasanuddin, \& Hartono, 2018), faktor-faktor yang mempengaruhi pemecahan masalah yaitu: (a) pengalaman awal, (b) latar belakang masalah matematika, (c) keinginan dan motivasi, dan (d) struktur masalah. Selain itu terdapat pula komponen-komponen dasar dalam menyelesaikan masalah yang sebagai mana dikemukakan oleh Glass dan Holyoak (Jacob, 2010) berikut: (a) tujuan atau deskripsi yang merupakan suatu solusi terhadap masalah, (b) Deskripsi objekobjek yang relevan untuk mencapai suatu solusi sebagai sumber yang dapat digunakan dan setiap perpaduan atau pertentangan yang dapat tercakup, (c) Himpunan operasi, atau tindakan yang diambil untuk membantu mencapai solusi, dan (d) Himpunan pembatas yang tidak harus dilanggar dalam pemecahan masalah.

Adapun indikator kemampuan pemecahan masalah matematis yaitu: (a) Mengidentifikasi unsur-unsur yang diketahui, ditanyakan, dan kecukupan unsur yang diperlukan, (b) Merumuskan masalah matematis atau model matematis, (c) Menerapkan strategi untuk menyelesaikan masalah dan (d) Menjelaskan atau menginterpretasikan hasil penyelesaian masalah(Lestari \& Yudhanegara, 2017).

Melihat adanya peluang untuk memanfaatkan teknologi multimedia pembelajaran interaktif dalam proses belajar dan perlunya masalah kontekstual untuk memfasilitasi kemampuan pemecahan masalah, tentu dicari materi yang sesuai dan menjadi banyak kendala dalam proses mengaitkan pada hal nyata sehingga memudahkan siswa dalam menyelesaikan persoalan pada materi tersebut. Salah satu materinya adalah materi himpunan. Dan juga pada materi himpunan ini berdasarkan hasil penelitian terdahulu menyimpulkan masih banyak siswa melakukan kesalahan atau tidak bisa menyelesaikan persoalaan yang berkaitan dengan materi himpunan tersebut(Hidayat \& Pujiastuti, 2019; Lusiana, 2017), sehingga harus dicarikan cara agar siswa tersebut lebih paham terhadap materi himpunan yaitu dengan mengembangkan multimedia interaktif agar bisa digunakan siswa baik ketika di kelas maupun ketika ingin mengulang materi di rumah.

Berdasarkan uraian tersebut, maka Salah satu cara memanfaatkan peluang tersebut adalah peneliti mengembangankan multimedia pembelajaran interaktif berbasis masalah kontekstual untuk memfasilitasi kemampuan pemecahan masalah matematis yang valid,praktis, dan efektif pada materi himpunan. Harapannya agar dengan dibuatnya multimedia ini dapat bermanfaat sebaga sarana dalam proses pembelajaran di kelas.

\section{METODE}

\section{Jenis Penelitian}

Jenis penelitian yang digunakan dalam penelitian ini adalah penelitian pengembangan (Research and Development /R\&D ). "Research and Development adalah rangkaian proses atau langkah-langah dalam rangka mengembangkan suatu produk baru atau menyempurnakan produk yang telah ada agar 
Pengembangan Multimedia Pembelajaran Interaktif Berbasis Masalah Kontekstual Pada Materi Himpunan untuk Memfasilitasi Kemampuan Pemecahan Masalah Matematis Siswa Sekolah Menengah Pertama, Sunarsih Puji Lestari, Hayatun Nufus, Ramon Muhandaz

dapat dipertanggungjawabkan (Trianto, 2010). Penelitian dan pengembangan yang dimaksud pada penelitian ini tujuannya untuk menghasilkan produk yang bisa digunakan sebagai bahan ajar. Produk yang dihasilkan berupa pengembangan dari produk bahan ajar yang telah ada sebelumnya. Pengembangan produk juga menggunakan model pengembangan yang melewati serangkaian proses seperti analisis kebutuhan, pengembangan produk, evaluasi serta revisi.

\section{Objek dan Subjek Penelitian}

Objek dalam penelitian ini adalah pengembangan multimedia pembelajaran interaktif berbasis masalah kontekstual pada materi himpunan untuk memfasilitasi kemampuan pemecahan masalah matematis siswa sekolah menengah pertama. Subjek dalam penelitian ini adalah para ahli sebagai validasi produk, dan siswa kelas VII SMP Juara Pekanbaru sebagai subjek uji praktikalitas dan efektifitas.

\section{Model Pengembangan}

Pada penelitian pengembangan ini, model pengembangan yang peneliti gunakan ialah model ADDIE (Analyse, Design, Development, Implementation, Evaluation). Model ADDIE mulai ada pada tahun 1990-an yang dikembangkan oleh Dick dan Carry yang digunakan untuk merancang sistem pembelajaran (Mulyatiningsih, 2012).

\section{Teknik Pengumpulan Data}

Teknik pengumpulan data berisi tentang untuk apa dan bagaimana cara mengumpulkan data-data penelitian ini. Adapun teknik yang digunakan adalah sebagai berikut:

1. Angket, digunakan untuk mengevaluasi produk multimedia pembelajaran interaktif yang sedang dikembangkan dengan mengikuti langkah-langkah berikut : (a)merumuskan tujuan, secara umum tujuannya adalah untuk mengetahui dan mengevaluasi kevalidan dari produk multimedia pembelajaran interaktif yang dikembangkan, (b)membagi angket menjadi beberapa bagian yaitu untuk ahli materi, ahli media dan siswa. angket diberikan kepada ahli media dan ahli materi untuk mengetahui kevalidan multimedia pembelajaran interaktif agar materi dan media yang disampaikan sesuai dengan tujuan pembelajaran matematika dan kemampuan yang ingin difasilitasi. angket juga diberikan kepada siswa untuk mengetahui praktikalitas produk multimedia pembelajaran interaktif, (c)menjabarkan bagian-bagian angket menjadi subbagian yang lebih spesifik. ini berisi sesuai indikator masing-masing ahli subjek penelitian, (d)menentukan jenis data untuk menentukan teknik analisis. data berupa data kuantitatif dan di analisis dengan deskriptif kuantitatif. Instrumen angket hanya validasi konten pakar.

2. Teknik Tes, Tes ini diberikan kepada siswa setelah menggunakan produk pengembangan multimedia pembelajaran interaktif dengan cara: (a)menentukan tujuan, tujuannya adalah untuk mengetahui pencapaian kemampuan pemecahan masalah matematis siswa,(b) membuat soal sesuai dengan indikator kemampuan pemecahan masalah matematis, materi pilihan serta melalui 
validasi soal,(c) membagikan kepada subjek penelitian untuk diisi. Instrumen angket dari hasil uji coba soal diperoleh hasil seperti tabel 1 berikut:

Tabel 1. Hasil Uji Coba Soal Tes Kemampuan Pemecahan Masalah

\begin{tabular}{|c|c|c|c|c|c|}
\hline No.soal & Validitas & Reliabilitas & Tingkat kesukaran & Daya Beda & keterangan \\
\hline 1 & Valid & \multirow{3}{*}{ Reliabilitas } & Sedang & Baik & Soal digunakan \\
\cline { 4 - 5 } 2 & Vaik & Sedang & $\begin{array}{c}\text { Sangat } \\
\text { baik }\end{array}$ & Soal digunakan \\
\cline { 5 - 6 } & valid & & sukar & baik & Soal digunakan \\
\hline
\end{tabular}

\section{Sumber: Data Olahan Peneliti}

\section{Teknik Analisis Data}

Teknik analisis data yang digunakan untuk mengolah data dari angket validitas dan angket praktikalitas produk pengembangan multimedia pembelajaran interaktif bersifat deskriptif, yang menggunakan teknik analisis deskriptif kuantitatif. Teknik analisis deskriptif kuantitatif berupa suatu cara pengolahan data yang dilakukan dengan jalan menyusun secara sistematis dalam bentuk angkaangka dan persentase, mengenai suatu objek yang diteliti, sehingga diperoleh kesimpulan umum. Objek yang diteliti pada penelitian ini adalah persepsi responden mengenai produk multimedia pembelajaran interaktif. Sedangkan untuk mengukur efektifitas dilakukan uji quasi eksperimen. Efektifitas media pembelajaran yang dikembangkan ditentukan dari perbedaan rata-rata posttest di kelas eksperimen dan rata-rata posttest di kelas kontrol. Jenis desain quasi eksperimen yang dipakai peneliti adalah The Nonequivalent Posttest-Only Control Group Design dengan sampel dipilih secara purposive sampling.

\section{HASIL DAN DISKUSI}

\section{Hasil}

\section{Tahap Analisis}

\section{Hasil Analisis Kebutuhan}

Berdasarkan analisis kebutuhan yang telah dilakukan, ditemukan bahwa bahan ajar yang selama ini digunakan dalam pembelajaran matematika berupa buku dan media pembelajaran berupa ubin atau benda-benda lainnya di kelas. Selain itu Kurangnya ketersediaan bahan ajar berupa media pembelajaran yang sesuai dengan minat siswa yang tinggi terhadap teknologi.

\section{Hasil Analisis Kurikulum}

Berdaasarkan subjek penelitian peneliti yaitu siswa kelas VII SMP Juara Pekanbaru, Setelah dilakukan observasi ke lapangan terhadap kurikulum di sekolah, maka dihasilkan bahwa SMP Juara Pekanbaru menggunakan kurikulum 13.

Hasil Analisis Karakteristik Siswa 
Pengembangan Multimedia Pembelajaran Interaktif Berbasis Masalah Kontekstual Pada Materi Himpunan untuk Memfasilitasi Kemampuan Pemecahan Masalah Matematis Siswa Sekolah Menengah Pertama, Sunarsih Puji Lestari, Hayatun Nufus, Ramon Muhandaz

Setelah menganalisis karakteristik siswa, ditemukan bahwa siswa memiliki karakteristik belajar yang beragam. ada yang lebih senang mendengar, menulis atau melihat apa yang ditulis di papan tulis. Siswa juga telah memiliki keterampilan menggunakan komputer walaupun masih keterampilan dasar. Pada tahap analisis karakteristik siswa menunjukkan bahwa meskipun tidak semua siswa memiliki komputer dirumahnya, tetapi mereka mampu menggunakan komputer. Hal ini karena mereka diajarkan menggunakan komputer bahkan ikut dalam ekstrakurikuler komputer. Hal ini sejalan dengan penelitian bahwa siswa sangat senang dan membuat hasil belajar menjadi lebih baik dengan multimedia(Damopolii, Bito, \& Resmawan, 2020).

\section{Tahap Design}

\section{Flowchart}

Flowchart ini menggambarkan secara menyeluruh alur program multimedia pembelajaran interaktif berbasis masalah kontekstual dari awal hingga akhir. Adapun flowchart yang dimaksud dapat dilihat pada Gambar 1 berikut ini:

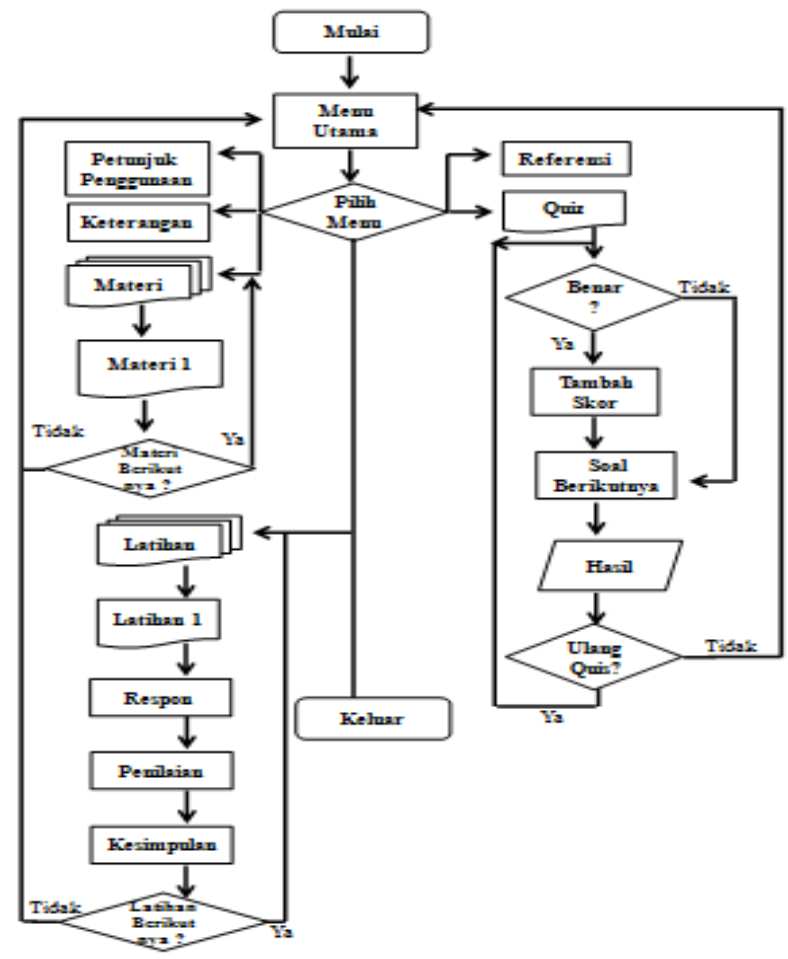

\section{Gambar 1. Flowchart}

Storyboard

Storyboard ini menyajikan disain tampilan multimedia pembelajaran interaktif. Adapun storyboard yang dimaksud dapat dilihat pada Gambar 2 sampai Gambar 7 berikut ini: 


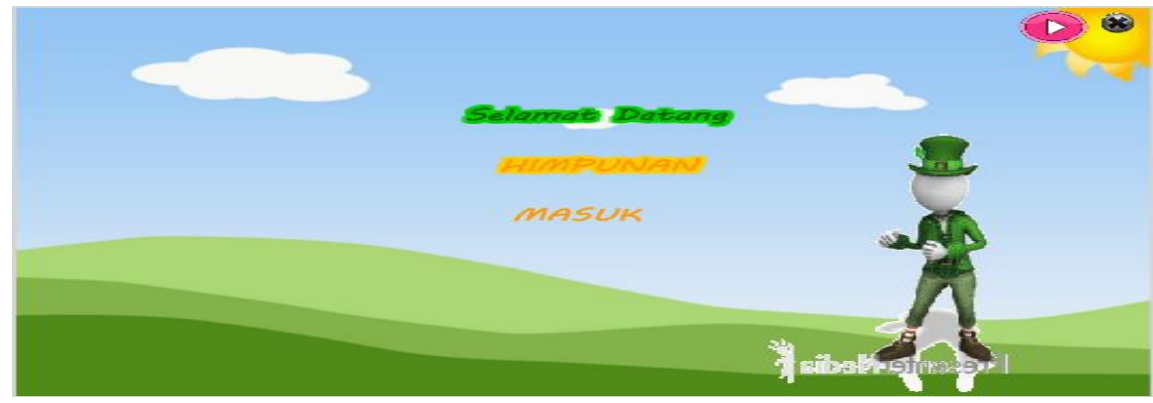

Gambar 2. Bagian Intro Multimedia

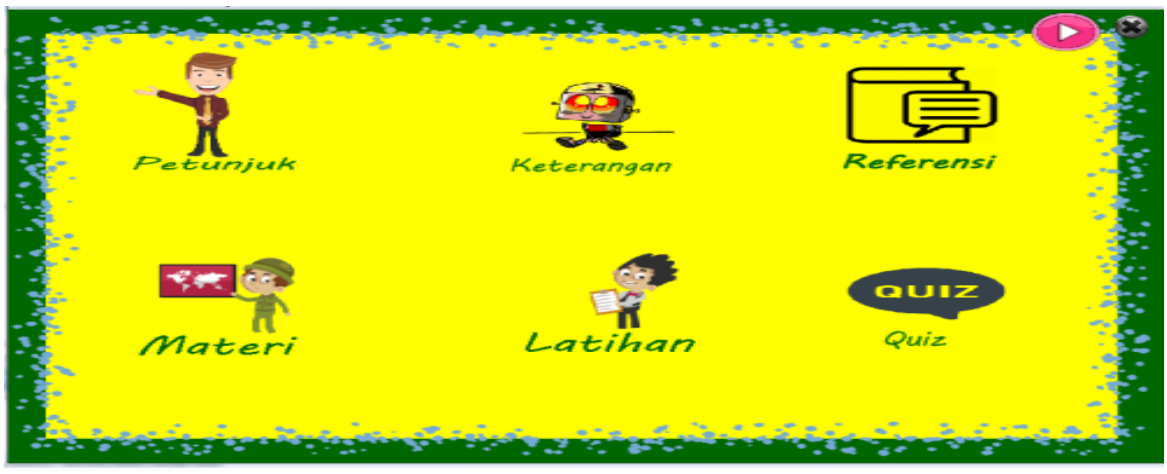

Gambar 3. Bagian Menu Multimedia

Pada tampilan intro terdapat tombol "MASUK" untuk menuju menu utama. Menu utama sendiri memiliki enam pilihan menu yaitu petunjuk, keterangaan, referensi, materi, latihan dan quiz.

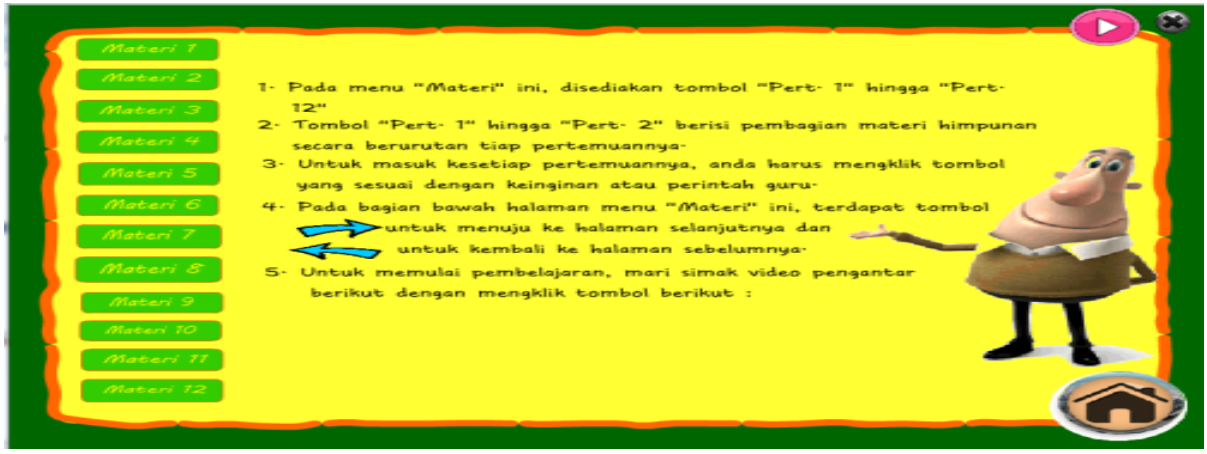

Gambar 4. Salah Satu Bagian Menu materi Multimedia

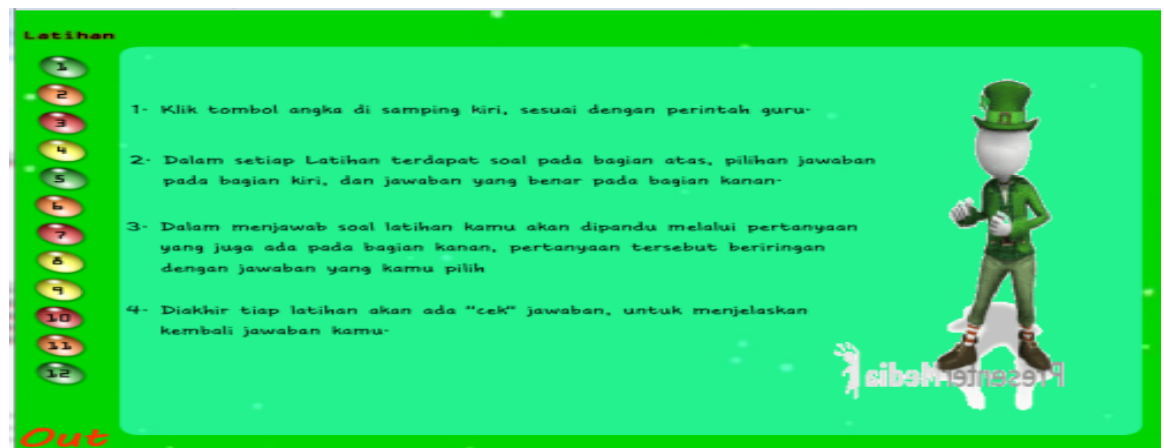

Gambar 5. Salah Satu Bagian Menu Latihan Multimedia

Menu materi dan latihan memiliki dua belas (12) sub menu. 
Pengembangan Multimedia Pembelajaran Interaktif Berbasis Masalah Kontekstual Pada Materi Himpunan untuk Memfasilitasi Kemampuan Pemecahan Masalah Matematis Siswa Sekolah Menengah Pertama, Sunarsih Puji Lestari, Hayatun Nufus, Ramon Muhandaz

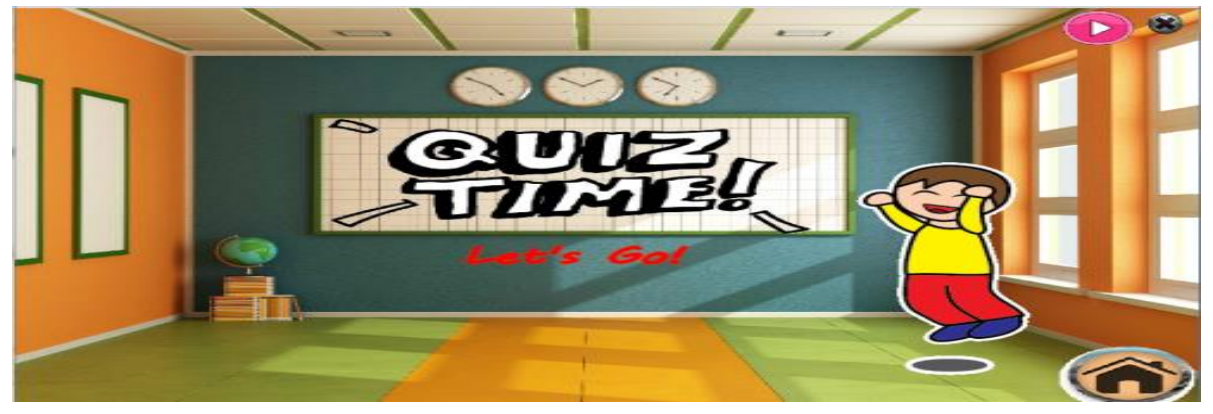

Gambar 6. Bagian Menu Masuk Kuis Multimedia

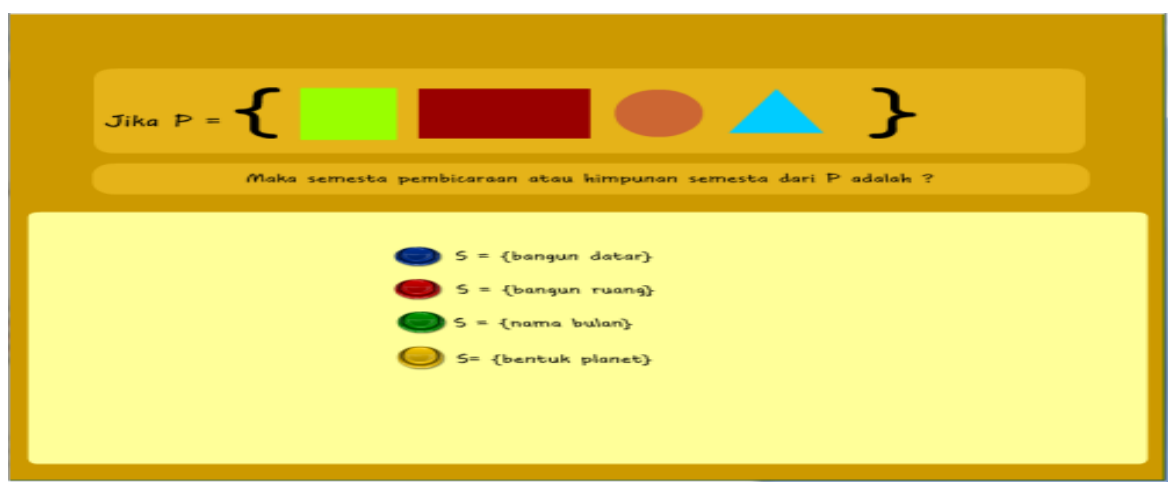

\section{Gambar 7. Salah Satu Bagian Menu Kuis Multimedia}

Menu quiz mencakup semua sub materi yang telah dipelajari dari menu materi.

\section{Tahap Development}

Hasil tahap analisis dan desain kemudian dikembangkan menjadi multimedia pembelajaran interaktif berbasis masalah kontekstual dan divalidasi oleh ahli materi dan ahli media. Berikut hasil validasi oleh ahli materi dapat dilihat pada Tabel 2 .

Tabel 2. Hasil Validasi oleh Ahli Materi

\begin{tabular}{|c|l|c|c|}
\hline No. & \multicolumn{1}{|c|}{ Variabel Validitas Multimedia } & $\begin{array}{c}\text { Nilai } \\
\text { Validasi }\end{array}$ & Kriteria \\
\hline 1 & Kelayakan Isi & $90 \%$ & Sangat Valid \\
\hline 2 & Bahasa & $78,75 \%$ & Valid \\
\hline 3 & Kemampuan Pemecahan Masalah & $92,5 \%$ & Sangat Valid \\
\hline \multicolumn{2}{|c|}{ Rata-Rata } & $\mathbf{8 6 , 9 2 \%}$ & Sangat Valid \\
\hline
\end{tabular}

Adapun hasil validasi oleh ahli media dapat dilihat pada Tabel 3 berikut. 
Tabel 3. Hasil Validasi oleh Ahli Media

\begin{tabular}{|c|c|c|c|}
\hline No. & $\begin{array}{c}\text { Variabel Validitas } \\
\text { Multimedia }\end{array}$ & Nilai Validasi & Kriteria \\
\hline 1 & Pemograman & $84 \%$ & Sangat Valid \\
\hline 2 & Tampilan & $76,82 \%$ & Valid \\
\hline \multicolumn{2}{|r|}{ Rata-Rata } & $80,41 \%$ & Valid \\
\hline
\end{tabular}

Berikut hasil penilaian validitas secara keseluruhan, yaitu hasil validasi ahli media dan hasil validasi ahli materi pembelajaran dapat dilihat pada Tabel 4 berikut:

Tabel 4. Hasil Validitas Secara Keseluruhan

\begin{tabular}{|c|c|c|c|}
\hline No. & $\begin{array}{c}\text { Indikator Penilaian } \\
\text { Validitas Multimedia }\end{array}$ & $\begin{array}{c}\text { Nilai } \\
\text { Validitas }\end{array}$ & Kriteria \\
\hline 1 & Ahli Media & $80,41 \%$ & Valid \\
\hline 2 & Ahli Materi & $86,92 \%$ & Sangat valid \\
\hline \multicolumn{2}{|c|}{ Rata-rata } & $\mathbf{8 3 . 6 7 \%}$ & Sangat Valid \\
\hline
\end{tabular}

\section{Tahap Implementation}

Data hasil praktikalitas

Data hasil praktikalitas kelompok kesil dan kelompok besar dapat dilihat pada Tabel 5 dan Tabel 6 berikut.

Tabel 5. Hasil Praktikalitas Kelompok Kecil

\begin{tabular}{|c|l|c|c|}
\hline No & $\begin{array}{c}\text { Indikator Penilaian } \\
\text { Praktikalitas Multimedia }\end{array}$ & $\begin{array}{c}\text { Nilai } \\
\text { Praktikalitas }\end{array}$ & Kriteria \\
\hline 1 & Tampilan & $87,5 \%$ & Sangat praktis \\
\hline 2 & Kelayakan Isi & $79,72 \%$ & praktis \\
\hline \multicolumn{2}{|c|}{ Rata-rata } & $\mathbf{8 3 . 6 1 \%}$ & Sangat praktis \\
\hline
\end{tabular}

Tabel 6. Hasil Praktikalitas Kelompok Besar

\begin{tabular}{|c|l|c|c|}
\hline No & $\begin{array}{c}\text { Indikator Penilaian Praktikalitas } \\
\text { Multimedia }\end{array}$ & $\begin{array}{c}\text { Nilai } \\
\text { Praktikalitas }\end{array}$ & Kriteria \\
\hline 1 & Tampilan & $85,3 \%$ & Sangat praktis \\
\hline 2 & Kelayakan Isi & $88,73 \%$ & Sangat praktis \\
\hline \multicolumn{2}{|c|}{ Rata-rata } & $\mathbf{8 7 . 0 2 \%}$ & Sangat praktis \\
\hline
\end{tabular}


Pengembangan Multimedia Pembelajaran Interaktif Berbasis Masalah Kontekstual Pada Materi Himpunan untuk Memfasilitasi Kemampuan Pemecahan Masalah Matematis Siswa Sekolah Menengah Pertama, Sunarsih Puji Lestari, Hayatun Nufus, Ramon Muhandaz

Setelah siswa pada kelompok terbatas mendapakan materi melalui multimedia pembelajaran interaktif berbasis masalah kontekstual. Peneliti memberikan posttest kepada siswa untuk menganalisis aspek efektivitas multimedia pembelajaran interaktif terhadap kemampuan pemecahan masalah matematis. Analisis dilakukan dengan membandingkan atau mencari perbedaan skor posttest kelas eksperimen dan kelas kontrol. Setelah dilakukan uji asumsi normalitas diperoleh $X_{\text {hitung }}^{2}>X_{\text {tabel }}^{2}$ yaitu 53,8346 $>$ 22,362 sehingga data tidak berdistribusi nornal, maka uji perbedaan yang peneliti pakai adalah uji non paramatrik yaitu uji Mann Whitney $U$. Berdasarkan hasil uji Mann Whitney U Posttest di dapatkan hasil sebagai berikut.

Tabel 7. Uji Mann Whitney U Posttest

\begin{tabular}{|c|c|c|}
\hline $\mathbf{Z}_{\text {hitung }}$ & $\mathbf{Z}_{\text {tabel }}$ & Keterangan \\
\hline$-5,557$ & 1,96 & Terdapat perbedaan \\
\hline
\end{tabular}

\section{Tahap Evaluation}

Pada tahap ini, multimedia pembelajaran interaktif dievaluasi kembali oleh peneliti. Peneliti melakukan revisi terakhir kepada multimedia pembelajaran interaktif berdasarkan saran atau masukan dari validator ahli ataupun siswa. Revisi terakhir ini dilakukan agar didapat multimedia pembelajaran interaktif yang sesuai dengan kebutuhan siswa dan sekolah. Saran yang telah diterima oleh peneliti dapat dilihat pada Tabel 8 berikut:

Tabel 8. Saran Terhadap Multimedia Pembelajaran Interaktif Berbasis Masalah Kontekstual

\begin{tabular}{|c|c|l|c|}
\hline No. & Validator & \multicolumn{1}{|c|}{ Saran } & Keterangan \\
\hline 1. & Ahli Media I & $\begin{array}{l}\text { Penambahan gambar animasi } \\
\text { dan video yang terkait dengan } \\
\text { materi }\end{array}$ & $\begin{array}{c}\text { Sudah } \\
\text { diperbaiki }\end{array}$ \\
\hline 2. & Ahli Media II & $\begin{array}{l}\text { Tutorial penggunaan aplikasi } \\
\text { berupa video bukan tulisan }\end{array}$ & $\begin{array}{c}\text { Sudah } \\
\text { diperbaiki }\end{array}$ \\
\hline 3. & Ahli Materi II & $\begin{array}{l}\text { Perbaikan letak animasi sesuai } \\
\text { materi dan beri sub judul }\end{array}$ & $\begin{array}{c}\text { Sudah } \\
\text { diperbaiki }\end{array}$ \\
\hline
\end{tabular}

\section{Pembahasan}

Pada penelitian pengembangan ini, peneliti menggunakan model pengembangan ADDIE (Analysis, Design, Development, Implementation, and Evaluation). Berdasarkan temuan pada tahap analisis yang telah dijelaskan dalam hasil penelitian. Dapat diketahui bahwa bahan ajar yang selama ini dipakai diantaranya adalah buku dan benda-benda di kelas seperti ubin dan lainnya. Sehingga media pembelajaran sangat dibutuhkan. Dalam hal ini peran media pembelajaran memiliki kontribusi 
dalam meningkatkan mutu dan kualitas pembelajaran di kelas (Kintoko, Sujadi, \& S, 2015). Selain itu ketersediaan bahan ajar berupa media pembelajaran yang sesuai dengan minat siswa yang tinggi terhadap teknologi ternyata masih kurang. Peneliti sempat menanyakan kepada salah seorang guru matematika tentang pemanfaatan laboratorium komputer yang disediakan sekolah untuk digunakan dalam pembelajaran matematika. Ternyata dalam proses pembelajaran matematika belum didukung media pembelajaran yang menggunakan akses komputer. Sementara itu menurut Warpala dalam empat hal pokok acuan untuk mencapai tujuan pembelajaran salah satunya adalah pemanfaatan potensi lingkungan yang multi situs dan dikenal baik oleh peserta didik sebagai sumber belajar(Warpala, 2019) . Sehingga adanya fasilitas laboratorium komputer di sekolah sebenarnya berpeluang untuk pemanfaatan komputer sebagai akses dalam pembelajaran. Dengan adanya komputer tersebut dapat dimanfaatkan untuk membuat multimedia pembelajaran interaktif. Hal ini didukung dengan pendapat Wibawanto yang mengatakan bahwa "Dengan adanya media pembelajaran maka tradisi lisan dan tulisan dalam proses pembelajaran dapat diperkaya dengan berbagai media pengajaran.”(Wibawanto, 2017). Tentunya hal ini dikarenakan media pembelajaran terutama dengan akses komputer dapat menyampaikan materi pembelajaran secara tekstual, audio maupun visual (Rosyida, 2017). Sehingga peneliti mengembangkan bahan ajar berupa multimedia pembelajaran interaktif. Agar multimedia pembelajaran interaktif yang dikembangkan dapat sesuai dengan kebutuhan sekolah yang bersangkutan, maka peneliti melakukan analisis terhadap kurikulum sekolah.

Hasil analisis kurikulum sekolah diketahui bahwa SMP Juara Pekanbaru menggunakan kurikulum 2013. Penentuan judul, kompetensi dasar serta indikator disesuaikan berdasarkan silabus yang digunakan sekolah tersebut. Setelah menentukan judul, kompetensi dasar dan indikator barulah dapat disusun fakta, konsep, prinsip, aturan dan prosedur serta tujuan pembelajaran pada RPP. Materi yang disampaikan juga menggunakan masalah-masalah kontekstual. Masalah kontekstual itu sendiri adalah masalah yang sesuai dengan situasi yang dialami siswa, sesuai dengan kehidupan nyata dan dekat dengan siswa (Rizki, 2018). Tujuan digunakannya masalah kontekstual dalam materi pembelajaran adalah agar materi tersebut dapat dirasa penting oleh siswa karena memiliki kaitan dengan keadaan lingkunganya atau hal-hal yang pernah ia temui. Sehingga siswa merasa materi yang ia terima bermanfaat bagi dirinya. Dengan demikian multimedia pembelajaran interaktif yang dikembangkan dapat sesuai dengan kurikulum sekolah serta menarik bagi siswa.

Setelah melakukan analisis kebutuhan dan analisis kurikulum, peneliti juga melakukan analisis karakteristik siswa agar multimedia pembelajaran yang dikembangkan dapat diterima dengan baik oleh siswa. Pada analisis karakteristik siswa ini, peneliti melihat adanya perbedaan gaya belajar siswa di dalam kelas. Gaya belajar dapat diartikan sebagai cara yang lebih disukai siswa dalam melakukan kegiatan berpikir, memproses dan mengerti suatu informasi dan pengetahuan dalam pembelajaran (Tanamir, Afryansih, \& Putri, 2019). Berdasarkan observasi yang dilakukan peneliti kepada siswa kelas VII. Ternyata ketika guru sedang menjelaskan materi pembelajaran menggunakan papan tulis. 
Pengembangan Multimedia Pembelajaran Interaktif Berbasis Masalah Kontekstual Pada Materi Himpunan untuk Memfasilitasi Kemampuan Pemecahan Masalah Matematis Siswa Sekolah Menengah Pertama, Sunarsih Puji Lestari, Hayatun Nufus, Ramon Muhandaz

Sebagian siswa benar-benar memperhatikan guru di depan kelas, namun sebagiannya lagi ada yang mengobrol, melamun bahkan ada yang mengantuk. Sebagaimana disampaikan oleh Rijal dan Bachtiar (Rijal \& Bachtiar, 2015) bahwa siswa sebagai orang yang sedang belajar dan berkembang memiliki keunikan dan karakter masing-masing dalam proses pembelajaran. Berkaitan dengan itu, adanya kemajuan teknologi saat ini selain sebagai tantangan sekaligus juga sebagai peluang untuk meningkatkan kualitas pembelajaran di dalam kelas(Sattriawan, Sutiarso, \& Rosidin, 2020). Maka peneliti memandang bahwa siswa-siswa tersebut membutuhkan variasi media dalam penyampaian materi yang sesuai dengan gaya belajar mereka yang senang mendengar, melihat atau mereka yang interaktif. Ini didukung dengan pendapat Suseno dan Ismail (Suseno \& Ismail, 2020) bahwa media pembelajaran sangat dibutuhkan untuk menunjang proses perkembangan kognitif anak di usia awal sekolah menengah pertama. Hal ini terbukti ketika peneliti mencoba menanyakan pendapat mereka jika pembelajaran matematika dilakukan menggunakan komputer. Siswa-siswa tersebut terlihat antusias dengan memberikan respon-respon sebagai berikut: "benar, Miss? Yes", "Berarti kita belajar di labor komputer kan, Miss?" "Ye, Hore, cup ana di komputer nomor 1" dan berbagai respon lainnya. Karena dengan dilakukannya pembelajaran menggunakan komputer siswa akan memilih menu sendiri, menggunakan headphone serta dapat melihat materi lebih jelas. Selain itu, berdasarkan informasi yang didapat dari salah seorang murid bahwa meskipun tidak semua siswa memiliki komputer di rumahnya, namun mereka sudah bisa menggunakan komputer karena telah ajari di sekolah terutama yang bergabung dalam ekstrakurikuler komputer. Ini menunjukkan adanya minat terhadap pembelajaran menggunakan multimedia dengan akses komputer. Hal ini diperkuat dengan pendapat Munir (Munir, 2013) yang mengemukakan bahwa multimedia dapat menyajikan informasi yang dapat dilihat, didengar dan dilakukan, sehingga multimedia sangatlah efektif untuk menjadi alat (tools) yang lengkap dalam proses pengajaran dan pembelajaran. Sebagaimana pula yang disampaikan oleh Wibawanto (Wibawanto, 2017)bahwa “Adanya media pembelajaran bahkan dapat mempercepat proses belajar mengajar menjadi efektif dan efisien dalam suasana yang kondusif, sehingga dapat membuat pemahaman peserta didik lebih cepat".

Setelah selesai melakukan tahap analisis, tahap selanjutnya yaitu tahap design atau tahap perancangan. Tahap perancangan ini mencakup 2 langkah, yaitu pembuatan flowchart dan pembuatan storyboard. Pada tahap pembuatan flowchart, peneliti merancang multimedia pembelajaran dengan memuat menu utama yang terdiri atas materi, latihan, referensi, quiz, petunjuk penggunaan dan keterangan. Alur program ini dimulai dengan intro sebelum masuk ke menu utama. Pada menu materi terdiri atas 12 sub materi. Pada Menu latihan juga terdiri atas 12 sub bagian. Menu latihan dirancang agar sesuai dengan indikator kemampuan pemecahan masalah. Hal ini dimaksudkan untuk menggiring siswa agar terbiasa melakukan pemecahan masalah.. Tiap sub bagian latihan tersebut akan diberikan clue atau petunjuk. Clue inilah yang menggiring siswa untuk memecahkan masalah yang diberikan. Menu latihan menjadi perhatian khusus peneliti karena disesuaikan dengan karakteristik 
siswa yang membutuhkan adanya interaksi. Interaksi yang dimaksud disini adalah umpan balik berupa koreksi atau deteksi kesalahan ketika mengerjakan latihan. Ini sesuai dengan apa yang disampaikan Daryanto (Daryanto, 2010) yaitu "Dalam lingkungan belajar preskriptif, umpan balik sering mengambil bentuk koreksi dan deteksi terhadap kesalahan yang dibuat". Pada menu referensi berisi sumber dari mana diperoleh komponen penyusun multimedia pembelajaran interaktif. Pada menu quiz berisi soal-soal quiz yang memiliki opsi jawaban a sampai d. Setiap memulai quiz siswa harus menyelesaikan soal-soal tersebut dan tidak dapat kembali ke menu utama sebelum memperoleh hasil atau nilai dari jawaban mereka yang ditampilkan pada akhir quiz. Pada menu petunjukkan penggunaan multimedia pembelajaran interaktif berisi video yang menampilkan bagian-bagian serta tata cara penggunaan tiap menunya. Pada menu keterangan berisi tentang informasi peneliti yang mengembangkan multimedia pembelajaran interaktif tersebut. Penjelasan tentang menu-menu yang ada pada flowchart ini disesuaikan dengan tahap analisis sebelumnya terutama pada karakteristik siswa. Menurut Darmawan (Darmawan, 2012), karakteristik siswa adalah segi-segi latar belakang pengalaman pembelajar yang berpengaruh terhadap efektivitas proses belajarnya. Maka desain flowchart dibuat sedemikian rupa agar tidak membingungkan siswa dalam penggunaannya. Kemudian dilanjutkan dengan pembuatan storyboard. Pada tahap ini menjelaskan lebih detail dari flowchart sebelumnya, adapun yang dilakukan pada storyboard ini diantaranya : pemilihan icon menu, animasi, grafik, diagram serta pemilihan warna. Semuanya diatur semenarik mungkin agar siswa yang memiliki karakteristik belajar lewat apa yang mereka lihat, dapat lebih antusias.

Tahap selanjutnya adalah development (pengembangan). Pada tahap ini dilakukan pembuatan multimedia pembelajaran interaktif dan merevisinya agar sesuai dengan tujuan pembelajaran. Pada proses validasi oleh ahli materi, validator menyarankan untuk memperbaiki letak animasi serta memberi sub judul pada menu materi. Tujuannya agar siswa tahu dan ingat sub materi apa yang sedang mereka pelajari. Berikut tampilan sebelum dan sesudah revisi yang dapat dilihat pada Gambar 8 .

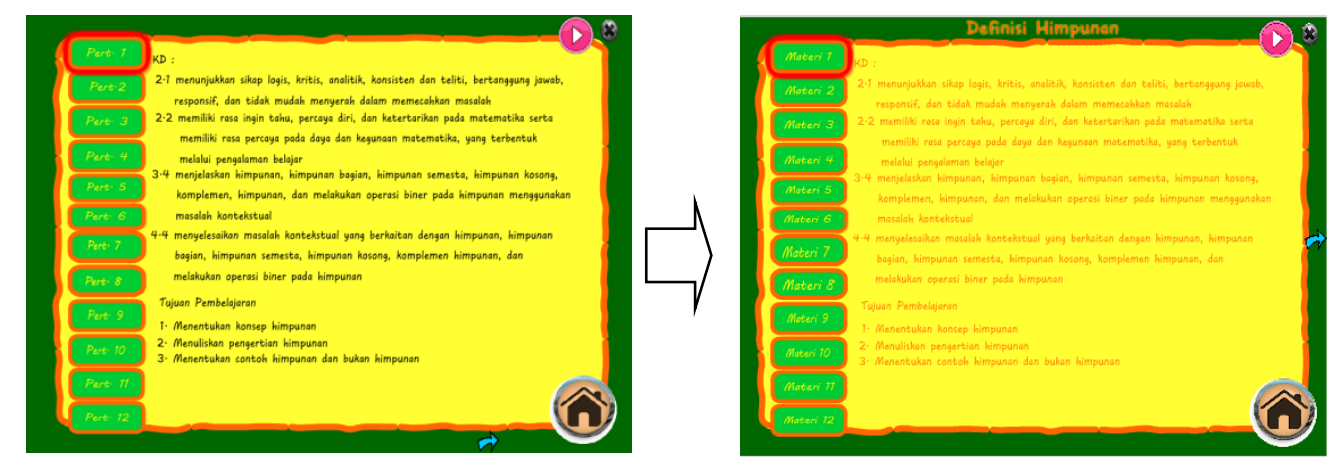

Gambar 8. Sebelum dan Sesudah Revisi 
Pengembangan Multimedia Pembelajaran Interaktif Berbasis Masalah Kontekstual Pada Materi Himpunan untuk Memfasilitasi Kemampuan Pemecahan Masalah Matematis Siswa Sekolah Menengah Pertama, Sunarsih Puji Lestari, Hayatun Nufus, Ramon Muhandaz

Berdasarkan hasil uji validitas materi persentase rata-ratanya adalah $86,92 \%$ dan ini masuk kedalam kategori sangat valid. Sehingga materi dalam multimedia pembelajaran ini sudah sesuai dengan indikator dan layak untuk diimplementasikan.

Pada proses validasi oleh ahli media, vaidator 1 menyarankan untuk menambahkan gambar animasi dan video yang terkait dengan materi himpunan. Hal ini agar multimedia yang dikembangkan memiliki komponen-kompenen yang lengkap. Berikut tampilan sebelum revisi yang dapat dilihat pada Gambar 9 berikut.

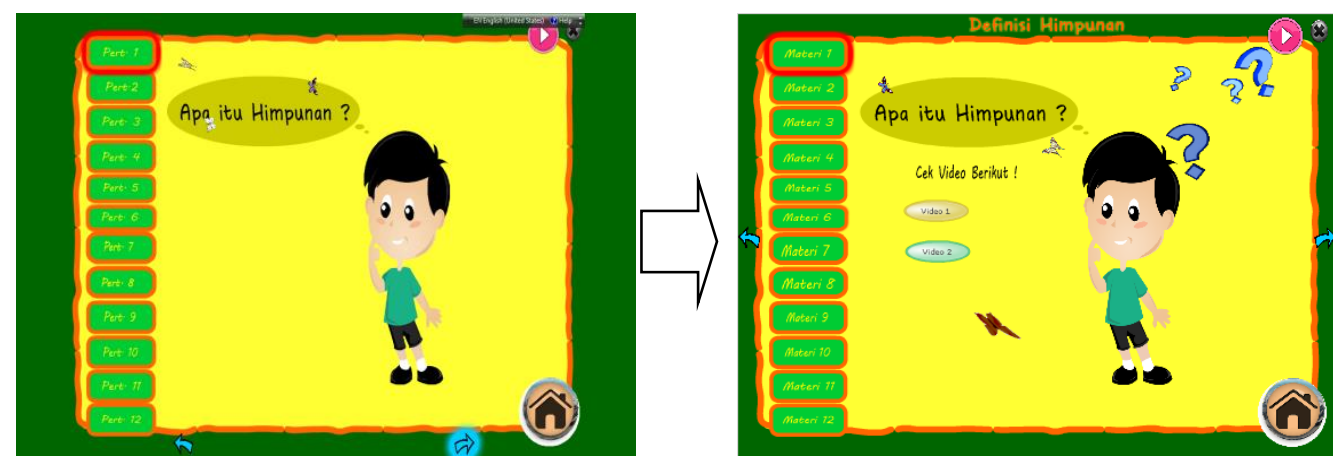

\section{Gambar 92. Sebelum dan Sesudah Revisi}

Selain itu ada juga saran dari validator 2 untuk mengubah petunjuk penggunaan yang semula berupa teks menjadi bentuk video. Berikut tampilan sebelum revisi yang dapat dilihat pada Gambar 10.

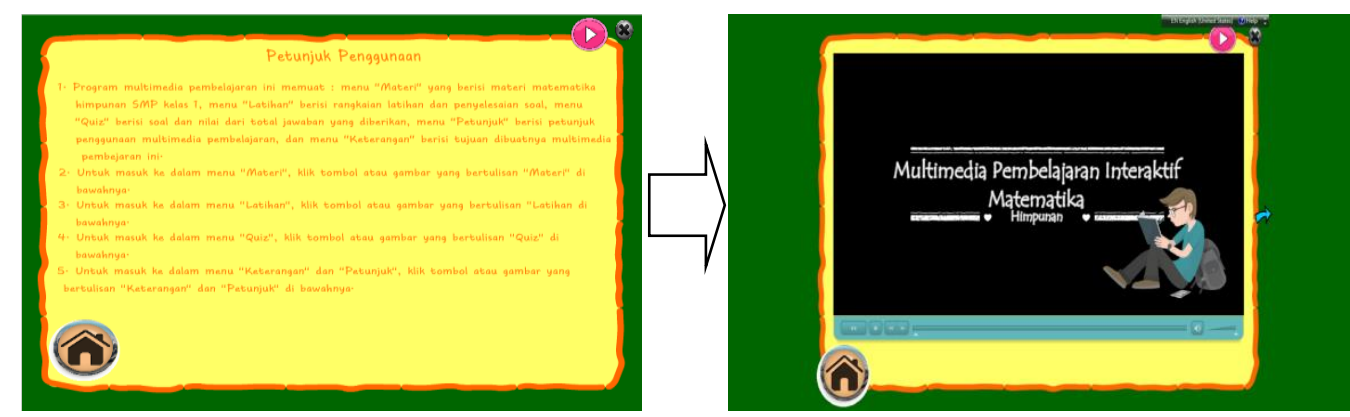

Gambar 10. Sebelum dan Sesudah Revisi

Adapun berdasarkan hasil validitas media persentase rata-ratanya adalah $80,41 \%$. Persentase rata-rata ini masuk dalam kategori valid sehingga Sehingga multimedia pembelajaran ini sudah sesuai dengan indikator dan layak untuk diimplementasikan. Kemudian dilanjutkan ketahap selanjutnya yaitu tahap implementation.

Pada tahap implementation, multimedia yang telah dinyatakan valid oleh ahli media dan ahli materi kemudian diuji cobakan kepada kelompok kecil yang terdiri atas 6 siswa. Hasil uji coba kelompok kecil menunjukkan rata-rata praktikalitas sebesar 83,61\% dengan kategori sangat praktis. 
Ini menunjukkan bahwa multimedia pembelajaran interaktif sudah layak dilanjutkan ke tahap selanjutnya. Sehingga peneliti melanjutkan kepada uji coba kelompok besar dengan perbaikan sesuai saran siswa. Berdasarkan hasil uji coba kelompok terbatas, persentase rata-rata praktikalitasnya adalah 87,02\% dengan kategori sangat praktis. Hasil uji coba ini sama dengan penelitian-penelitian serupa yang terdahulu tentang pengembangan media berbasis CTL (Norhayati et al., 2018) dan pengembangan media CD interaktif (Maharani \& Basir, 2016).

Setelah dilakukan uji praktikalitas, kemudian dilanjutkan dengan posttest untuk mengetahui efektivitas multimedia pembelajaran interaktif terhadap kemampuan pemecahan masalah matematis. Berdasarkan hasil uji Mann Whiteney $U$ terhadap posttest yang diberikan menunjukkan bahwa terdapat perbedaan kemampuan pemecahan masalah matematis yang signifikan antara kelas eksperimen dan kelas kontrol. Dengan rata-rata kelas eksperimen 69,33 dan kelas kontrol 35,61. Ini menunjukkan bahwa multimedia pembelajaran interaktif berbasis masalah kontekstual yang dikembangkan efektif untuk memfasilitasi kemampuan pemecahan masalah matematis siswa.

Coba kita perhatikan diagram batang tentang persentase tiap indikator kemampuan pemecahan masalah matematis siswa pada Gambar 11 berikut:

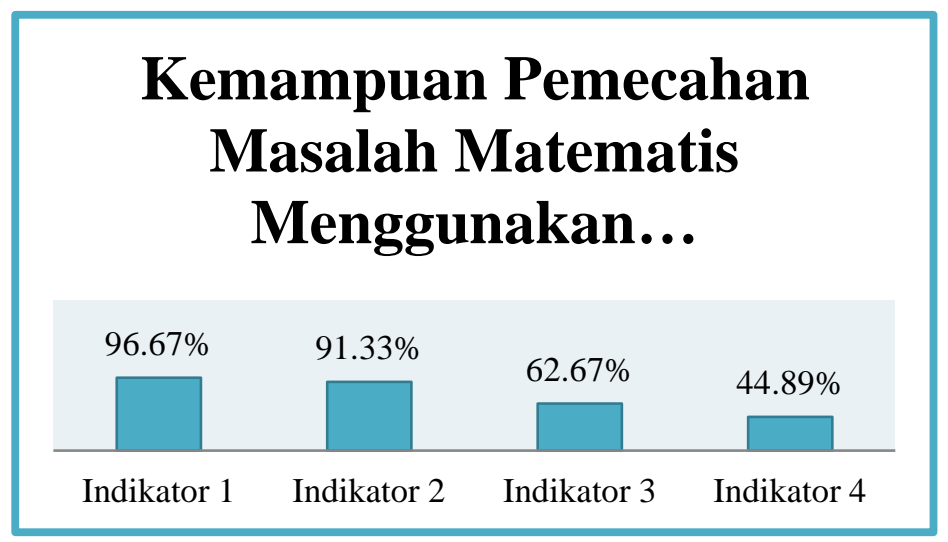

\section{Gambar 11. Kemampuan Pemecahan Matematis Setelah Perlakuan Penggunan LKS}

Berdasarkan Gambar 14 diatas dapat diketahui persentase masing-masing indikator yang didapatkan setelah menggunakan multimedia pembelajaran interaktif. Ternyata meskipun multimedia pembelajaran tersebut efektif serta didapatkan rata-rata kelas eksperimen lebih baik dari rata-rata kelas kontrol. terdapat sebuah indikator yang masih dalam kategori kurang yaitu indikator ke-4 dengan rata-rata 44,89\%. Dimana telah diketahui bahwa indikator ke-4 adalah menjelaskan atau menginterpretasikan hasil penyelesaian masalah. Ini menunjukkan bahwa siswa masih kurang mampu dalam menjelaskan atau menginterpretasikan hasil penyelesaian masalah. Hal ini dikarenakan kebanyakan siswa belum mampu melakukan pengecekan terhadap jawaban atau belum mampu memberikan kesimpulan dengan benar. 
Pengembangan Multimedia Pembelajaran Interaktif Berbasis Masalah Kontekstual Pada Materi Himpunan untuk Memfasilitasi Kemampuan Pemecahan Masalah Matematis Siswa Sekolah Menengah Pertama, Sunarsih Puji Lestari, Hayatun Nufus, Ramon Muhandaz

Setelah melalui tahap implementasi produk pengembangan tersebut kemudian dievaluasi. Pada tahap evaluasi ini setiap saran yang diterima dari para ahli dan juga siswa digunakan sebagai bahan revisi terakhir.

\section{KESIMPULAN}

Berdasarkan hasil penelitian dapat disimpulkan bahawa multimedia pembelajaran interaktif berbasis masalah kontekstual pada materi himpunan untuk memfasilitasi kemampuan pemecahan masalah matematis siswa kelas VII sekolah menengah pertama (SMP) Juara Pekanbaru mencapai kriteria sangat valid, dengan persentase validitas secara keseluruhan 83,67\%. Dan Mencapai kriteria sangat praktis, dengan persentase praktikalitas kelompok kecil sebesar 83,61\% dan kelompok terbatas sebesar 87,02\%. Serta efektif dengan rata-rata kelompok eksperimen sebesar 69,33 dan kelompok kontrol sebesar 35,61 sehingga dapat dimanfaatkan oleh guru dan siswa dalam proses pembelajaran di kelas.

\section{UCAPAN TERIMA KASIH}

Ucapan terima kasih disampaikan kepada semua pihak yang telah membantu dalam penyelesaian artikel ini mulai dari pihak sekolah, validator, serta pembimbing.

\section{REFERENSI}

Arifin, Y., Ricky, M. Y., \& Yesmaya, V. (2015). Digital Multimedia. Jakarta: Bina Nusantara Media \& Publishing.

Asmi, A. W., Rahmat, F., \& Muhandaz, R. (2021). The Effectiveness of Project Based Learning Students Worksheet on Students' Achievements in Two Variables Linear Equations System. Jurnal Pendidikan Sains dan Matematika Malaysia, 11 (Special issue), 59-71. https://doi.org/https://doi.org/10.37134/jpsmm.vol11.sp.6.2021

Badan Pusat Statistik. (2018). Penggunaan dan Pemanfaatan Teknologi Informasi dan Komunikasi (P2TIK) Sektor Pendidikan 2018. Diambil dari Badan Pusat Statistik website: https://www.bps.go.id/publication/2018/12/24/27971845a9d616341333d103/penggunaan-danpemanfaatan-teknologi-informasi-dan-komunikasi--p2tik--sektor-pendidikan-2018.html

Damopolii, V., Bito, N., \& Resmawan, R. (2020). Efektivitas Media Pembelajaran Berbasis Multimedia Pada Materi Segiempat. ALGORITMA: Journal of Mathematics Education, 1(2), 74-85. https://doi.org/10.15408/ajme.v1i2.14069

Darmawan, D. (2012). Inovasi Pendidikan Pendekatan Praktik Teknologi Multimedia dan Pembelajaran Online. Bandung: PT Remaja Rosdakarya.

Daryanto. (2010). Media Pembelajaran Peranannya Sangat Penting Dalam Mencapai Tujuan Pembelajaran. Yogyakarta: Gava Media.

Hendriana, H., Rohaeti, E. E., \& Sumarmo, U. (2017). Hard Skills dan Soft Skills Matematika Siswa. Bandung: PT Refika Aditama. 
Hidayat, D. W., \& Pujiastuti, H. (2019). Analisis kesalahan siswa dalam Menyelesaikan Masalah Matematis pada Materi Himpunan. Jurnal Analisa, 5(1). Diambil dari https://journal.uinsgd.ac.id/index.php/analisa/article/view/4120/3060

Jacob. (2010). Matematika Sebagai Pemecahan Masalah. Diambil dari http://file.upi.edu/browse.php?dir=Direktori/FPMIPA/JUR._PEND._MATEMATIKA/1945071 61976031-CORNELIS_JACOB/

Kintoko, Sujadi, I., \& S, D. R. S. (2015). Pengembangan Media Pembelajaran Matematika Berbantuan Komputer dengan Lectora Authoring Tools pada Materi Bangun Ruang Sisi Datar Kelas VIII SMP/MTS. Jurnal Elektronik Pembelajaran Matematika, 3, No.2, http://jurnalfkip.uns.ac.id.

Krulik, S., Rudnick, J. A., \& Milou, E. (2003). Teaching mathematics in middle school: a practical guide. Boston: Allyn and Bacon.

Lestari, K. E., \& Yudhanegara, M. R. (2017). Penelitian Pendidikan Matematika Panduan Praktis Menyusun Skripsi, Tesis, dan Karya Ilmiah dengan Pendekatan Kuantitatif, Kualitatif, dan Kombinasi Disertai dengan Model Pembelajaran dan Kemampuan Matematis. Bandung: PT Refika Aditama.

Lusiana, R. (2017). Analisis Kesalahan Mahasiswa Dalam Memecahkan Masalah Pada Materi Himpunan Ditinjau Dari Gaya Kognitif. Jurnal Penelitian dan Pembelajaran Matematika, 10(1). https://doi.org/10.30870/jppm.v10i1.1290

Maharani, H. R., \& Basir, M. A. (2016). Pengembangan Media CD Interaktif Matematika untuk Meningkatkan Kemampuan Pemecahan Masalah Siswa SMP. Jurnal Refleksi Edukatika, 7 (1). Diambil dari http://jurnal.umk.ac.id/index.php/RE

Mulyatiningsih, E. (2012). Metode Penelitian Terapan Bidang Pendidika. Bandung: Alfabeta.

Munir. (2013). Multinedia Konsep \& Aplikasi dalam Pendidikan. Bandung: Alfabeta.

Nelissen, J. M. C. (1999). Thinking skills in realistic mathematics. In Teaching and learning thinhing skills (hal. 189-213). Lisse [Netherlands]; Exton, PA: Swets \& Zeitlinger Publisher.

Nissa, I. C. (2015). Pemecahan Masalah Matematika (Teori dan Contoh Praktek). Lombok: Duta Pustaka Ilmu.

Norhayati, Hasanuddin, \& Hartono. (2018). Pengembangan Media Pembelajaran Berbasis Contextual Teaching and Learning untuk Memfasilitasi Kemampuan Pemecahan Masalah Matematis Siswa Madrasah Tsanawiyah. Juring (Journal for Research in Mathematics Learning), 1, No, 1.

Rijal, S., \& Bachtiar, S. (2015). Hubungan antara Sikap, Kemandirian Belajar dan Gaya Belajar dengan Hasil Belajar Kognitif Siswa. Jurnal BIOEDUKATIKA, (Vol. 3, No. 2).

Rizki, M. (2018). Profil Pemecahan Masalah Kontekstual Matematika oleh Siswa Kelompok Dasar. Jurnal Dinamika Penelitian Media Komunikasi Sosial Keagamaan, (volume 18, Nomor 02).

Rosyida, S. (2017). Multimedia Interaktif sebagai Media Pembelajaran Tentang Pengenalan Vitamin yang Terkandung di Dalam Buah. Jurnal Teknik Informatika STMIK Antar Bangsa, 3 No. 1. 
Pengembangan Multimedia Pembelajaran Interaktif Berbasis Masalah Kontekstual Pada Materi Himpunan untuk Memfasilitasi Kemampuan Pemecahan Masalah Matematis Siswa Sekolah Menengah Pertama, Sunarsih Puji Lestari, Hayatun Nufus, Ramon Muhandaz

Sattriawan, A., Sutiarso, S., \& Rosidin, U. (2020). Pengembangan Media Pembelajaran Interaktif Terintegrasi Soft Skills dalam Meningkatkan Kemampuan Pemecahan Masalah. Jurnal Cendekia: Jurnal Pendidikan Matematika, 04, No. 02.

Suseno, P. U., \& Ismail, S. (2020). Pengembangan Media Pembelajaran Matematika Video Interaktif Berbasis Multimedia. Jambura Jurnal of Mathematics Education, 01, Nomor 2.

Tanamir, M. D., Afryansih, N., \& Putri, R. E. (2019). Pengenalan Karakteristik Gaya Belajar Siswa Korong Suangkek Kanagarian Sungai Durian Kecamatan Patamuan Kabupaten Padang Pariaman. Rangkiang: Jurnal Pengabdian Pada Masyarakat, (Vol. 1, No. 2). Diambil dari http://ejournal.stkip-pgri-sumbar.ac.id/index.php/rangkiang

Trianto. (2010). Pengantar Penelitian Pendidikan bagi Pengembangan Profesi dan Tenaga Kependidikan. Jakarta: Dian Rakyat.

Warpala, I. W. S. (2019a). Pembelajaran Kontekstual: Sebuah Inovasi Penerapan Pendidikan Multikultural dan Belajar untuk Penemuan. Media Edukasi: Jurnal Ilmu Pendidikan, 3(1). Diambil dari https://jurnal.undhirabali.ac.id/index.php/jmk/article/view/729

Warpala, I. W. S. (2019b). Pembelajaran Kontekstual: Sebuah Inovasi Penerapan Pendidikan Multikultural dan Belajar untuk Penemuan. Media Edukasi: Jurnal Ilmu Pendidikan, (Volume 3, Nomor 1).

Wibawanto, W. (2017). Desain dan Pemrograman Multimedia Pembelajaran Interaktif. Jember, Jawa Timur: Penerbit Cerdas Ulet Kreatif.

Wina, S. (2012). Media Komunikasi Pembelajaran. Jakarta: Kencana Prenada Media Group. 